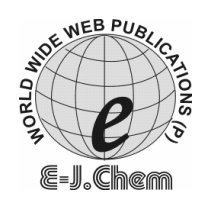

ISSN: 0973-4945; CODEN ECJHAO

E-Journal of Chemistry

http://www.e-journals.net

2009, 6(4), 1085-1090

\title{
Three-Dimensional Supramolecular Network Directed by Intermolecular Interactions in $\left[\mathrm{Pb}_{2}(\mathrm{dmp})_{2}(\mathrm{hfacac})_{4}\right]$
}

\author{
FARZIN MARANDI ${ }^{*}$, LOTFALI SAGHATFOROUSH \\ and HOSSEIN FARZANEH ${ }^{\S}$ \\ *Department of Science, Payame Noor University (PNU), Zanjan, Iran. \\ Department of Science, Payame Noor University (PNU), Khoy, Iran. \\ ${ }^{\S}$ Department of Science, Zanjan University, Zanjan, Iran \\ fmarandi2004@yahoo.com
}

Received 25 January 2009; Accepted 18 March 2009

\begin{abstract}
To investigate the interactions between noncovalent bond donor and acceptor giving rise to three dimensional networks, compound $\left[\mathrm{Pb}_{2}(\mathrm{dmp})_{2}(\mathrm{hfacac})_{4}\right](\mathbf{1})(\mathrm{dmp}=2,9$-dimethyl-1,10-phenanthroline and Hhfacac $=$ hexafluoroacetylacetonate) has been prepared and characterized by elemental analysis, IR, ${ }^{1} \mathrm{H}$ NMR, and ${ }^{13} \mathrm{C}$ NMR spectroscopy and its crystal structures was investigated. The single crystal structure show the coordination number of $\mathrm{Pb}(\mathrm{II})$ to be eight with two $N$-donor atoms from a "dmp" ligand and six $O$-donors from the anionic ligands. The supramolecular structure of $\mathbf{1}$ is realized by weak directional $\mathrm{C}-\mathrm{H} \cdots \mathrm{O}-\mathrm{C}, \mathrm{C}-\mathrm{F} \cdots \mathrm{F}-\mathrm{C}$ and $\pi-\pi$ stacking interactions.
\end{abstract}

Keywords: Crystal structure, Lead(II) complex, Intermolecular interactions

\section{Introduction}

Control of the supramolecular solid state organization of individual molecules is one of the most important ways to develop novel functional materials. In this field the use of molecular self-organization processes for the development of self-assembled and self-organized structures has attracted attention both in biology and in materials chemistry ${ }^{1}$. Understanding of charge assisted non-covalent interactions such as hydrogen bonding, $\pi-\pi$ stacking, dipole-dipole, hydrophobic interactions, etc., collectively constitute a promising field of persistent research interest ${ }^{2}$. Molecular organization into one-, two-, or three-dimensional networks is mainly driven by noncovalent interactions, of which hydrogen bonding (of both the strong and the weak variations) plays an important role ${ }^{3,4}$. Weak hydrogen bonding can play a role in enzymatic reactions because it is capable of modulating the bonding situation in 
catalytic sites to a significant degree, thus influencing catalytic properties ${ }^{3 b}$. The construction of metallo-supramolecular systems based on these types of intermolecular interactions is becoming of wide interest nowadays. Recently in an effort to explore weak interactions in complexes, the lead(II) complexes with $\beta$-diketonate and neutral diimine chelating ligands have been synthesized and determined by X-ray crystal structure ${ }^{5-8}$. In this paper we report the synthesis and crystal structures of $\left[\mathrm{Pb}_{2}(\mathrm{dmp})_{2}(\mathrm{hfacac})_{4}\right] \mathbf{1}$ (dmp and hfacac are the abbreviations of 2,9-dimethyl-1,10-phenanthroline and hexafluoroacetylacetonate ligands, respectively, which have the potential to generate intermolecular interactions).

\section{Experimental}

IR spectra were recorded as nujol mulls using Perkin-Elmer 597 and Nicolet 510P spectrophotometers. Microanalyses were carried out using a Heraeus CHN-O- Rapid analyzer. Melting points were measured on an Electrothermal 9100 apparatus and are uncorrected. ${ }^{1} \mathrm{H}$ NMR spectra were measured with a BRUKER DRX-500 AVANCE spectrometer at $500 \mathrm{MHz}$.

\section{Preparation of $\left[\mathrm{Pb}_{2}(\mathrm{dmp})_{2}(\text { hfacac })_{4}\right](\mathbf{1})$}

2,9-Dimethyl-1,10-phenanthroline $(0.217 \mathrm{~g}, 1 \mathrm{mmol})$ was placed in one arm of a branched tube ${ }^{9}$ and lead(II)acetate $(0.36 \mathrm{~g}, 1 \mathrm{mmol})$, and "Hhfacac" ligand $(0.416 \mathrm{~g}, 2 \mathrm{mmol})$ in the other. Methanol was carefully added to fill both arms, the tube sealed and the ligandcontaining arm immersed in a bath at $60{ }^{\circ} \mathrm{C}$ while the other was at ambient temperature. After 3 days, crystals had deposited in the cooler arm which were filtered off, washed with acetone and ether and air dried. Yield: $75 \%$, m.p. $=230{ }^{\circ} \mathrm{C}$. (Found, C: $34.80, \mathrm{H}: 1.80, \mathrm{~N}$ : $3.30 \%$. calculated for $\mathrm{C}_{24} \mathrm{H}_{14} \mathrm{~F}_{12} \mathrm{~N}_{2} \mathrm{O}_{4} \mathrm{~Pb}: \mathrm{C}: 34.73, \mathrm{H}: 1.70, \mathrm{~N}: 3.38 \%$.). IR $\left(\mathrm{cm}^{-1}\right): 701 \mathrm{~m}$, $763 \mathrm{~m}, 1018 \mathrm{~m}, 1149 \mathrm{~s}, 1280 \mathrm{vs}, 1473 \mathrm{~s}, 1533 \mathrm{~s}^{10}, 2990 \mathrm{~m}$ and $3070 \mathrm{w} .{ }^{1} \mathrm{H}$ NMR (DMSO, $\delta$ ): 2.79(s, 6H), 5.40(s, 2H), 7.64(m, 2H), 7.86(d, 2H), $8.23(\mathrm{~m}, 2 \mathrm{H}) \mathrm{ppm} .{ }^{13} \mathrm{C}$ NMR (DMSO, $\left.\delta\right)$ : 25.38, 83.74, 124.12, 126.02, 127.24, 137.13, 145.13, 145.07, 158.88, 177.72.

\section{Crystallography}

The structure was solved by direct methods and refined by full matrix least squares using SHELXL- $97^{11,12}$. SHELX operations were automated using ORTEX, which was also used to obtain the drawings ${ }^{13}$. Data were corrected for Lorentz and polarization effects but not for absorption. Hydrogen atoms were included in calculated positions with thermal parameters $30 \%$ larger than the atom to which they were attached. The non hydrogen atoms were refined anisotropically. All calculations were performed on a Pentium PC.

\section{Results and Discussion}

Determination of the structure of $\left[\mathrm{Pb}_{2}(\mathrm{dmp})_{2}(\text { hfacac })_{4}\right]$ by X-ray crystallography (Table 1 ) showed the complex to be dinuclear in the solid state. The crystallographic unit of $\left[\mathrm{Pb}_{2}(\mathrm{dmp})_{2}(\mathrm{hfacac})_{4}\right]$ is illustrated in the ORTEP-3 plot Figure 1 and it consists of two lead(II) ions coordinated to two dmp molecules and four "hfacac" ligands. The coordination number of Lead(II) ions in $\left[\mathrm{Pb}_{2}(\mathrm{dmp})_{2}(\text { hfacac })_{4}\right]$ is eight (two of bidentate "dmp", two of bidentate "hfacac" "anions and four of two bridging "hfacac" ligands). Distances of $\mathrm{Pb}-\mathrm{O}$ bonds with terminal "hfacac" ligands are less than bridging "hfacac" ligands Table 2. It is possible, nonetheless, to view the $\mathrm{Pb}$ atoms of asymmetric units as linked via $\mathrm{Pb}_{2} \mathrm{O}_{2}$ rhombs, structurally a feature of many $\mathrm{Pb}(\mathrm{II})$ complex structures ${ }^{6,8 b, 14-16}$, involving these four hfacac$\mathrm{O}$ atoms and which may be indicative of very weak $\mathrm{Pb} \cdots \mathrm{Pb}$ bonding ${ }^{17}$ aided by the $O$-donoratom bridging. The $\mathrm{Pb}$ atom with a coordination number of 8 possesses a stereo-chemically 'inactive' lone pair, and the coordination sphere is holodirected ${ }^{18}$ (Figure 1). 
Table 1. Crystal data and structure refinement details for $\left[\mathrm{Pb}_{2}(\mathrm{dmp})_{2}(\mathrm{hfacac})_{4}\right]$.

\begin{tabular}{|c|c|}
\hline Empirical formula & $\mathrm{C}_{24} \mathrm{H}_{14} \mathrm{~F}_{12} \mathrm{~N}_{2} \mathrm{O}_{4} \mathrm{~Pb}$ \\
\hline Formula weight & 829.56 \\
\hline Temperature & $298(2) \mathrm{K}$ \\
\hline Wavelength & $0.71069 \AA$ \\
\hline Crystal system & Triclinic \\
\hline Space group & $\mathrm{P} 1$ \\
\hline Unit cell dimensions & $\begin{array}{l}\mathrm{a}=11.108(1) \AA \alpha=99.07(2) \mathrm{deg} \\
\mathrm{b}=12.614(2) \AA \beta \\
\mathrm{c}=11.312(1) \AA \gamma=110.68(2) \mathrm{deg}\end{array}$ \\
\hline Volume & $1322.7(4) \AA^{3}$ \\
\hline $\mathrm{Z}$ & 1 \\
\hline Density (calculated) & $2.083 \mathrm{Mg} / \mathrm{m}^{3}$ \\
\hline Absorption coefficient & $6.497 \mathrm{~mm}^{-1}$ \\
\hline $\mathrm{F}(000)$ & 788 \\
\hline Crystal size & $0.43 \times 0.35 \times 0.32 \mathrm{~mm}$ \\
\hline Theta range for data collection & 1.81 to $22.98 \mathrm{deg}$. \\
\hline Index ranges & $-10<=\mathrm{h}<=10 ;-11<=\mathrm{k}<=10 ;-12<=\mathrm{l}<=12$ \\
\hline Reflections collected & 5268 \\
\hline Independent reflections & $4492[\mathrm{R}(\mathrm{int})=0.0275]$ \\
\hline Reflections observed, $>2 \sigma$ & 4304 \\
\hline Data Completeness & 0.663 \\
\hline Absorption correction & PSI-Scans \\
\hline Refinement method & Full-matrix least-squares on $\mathrm{F}^{2}$ \\
\hline Data / restraints / parameters & 4492 / 93 / 536 \\
\hline Goodness-of-fit on $\mathrm{F}^{2}$ & 1.229 \\
\hline Final $R$ indices, $I>2 \sigma(I)$ & $\mathrm{R}_{1}=0.0348 \quad w \mathrm{R}_{2}=0.0907$ \\
\hline $\mathrm{R}$ indices (all data) & $\mathrm{R}_{1}=0.0361 \quad w \mathrm{R}_{2}=0.0916$ \\
\hline Absolute structure parameter & $0.0(18)$ \\
\hline Largest diff. peak and hole & 0.690 and -0.962 e. $\AA^{-3}$ \\
\hline
\end{tabular}

Table 2. Selected bond lengths / $\AA$ and angles $/{ }^{\circ}$ for $\left[\mathrm{Pb}_{2}(\mathrm{dmp})_{2}(\mathrm{hfacac})_{4}\right]$.

\begin{tabular}{llll}
\hline $\mathrm{Pb} 1-\mathrm{N} 3$ & $2.32(2)$ & $\mathrm{Pb} 1-\mathrm{N} 4$ & $2.56(2)$ \\
\hline $\mathrm{Pb} 1-\mathrm{O} 3$ & $2.67(2)$ & $\mathrm{Pb} 1-\mathrm{O} 5$ & $2.85(3)$ \\
$\mathrm{Pb} 1-\mathrm{O} 6$ & $2.86(3)$ & $\mathrm{Pb} 1-\mathrm{O} 7$ & $2.90(3)$ \\
$\mathrm{Pb} 1-\mathrm{O} 8$ & $2.71(3)$ & $\mathrm{Pb} 1-\mathrm{O} 4$ & $2.92(2)$ \\
$\mathrm{Pb} 2-\mathrm{N} 2$ & $2.39(2)$ & $\mathrm{Pb} 2-\mathrm{N} 1$ & $2.57(3)$ \\
$\mathrm{Pb} 2-\mathrm{O} 2$ & $2.70(2)$ & $\mathrm{Pb} 2-\mathrm{O} 6$ & $2.70(2)$ \\
$\mathrm{Pb} 2-\mathrm{O} 1$ & $2.72(2)$ & $\mathrm{Pb} 2-\mathrm{O} 5$ & $2.88(2)$ \\
$\mathrm{Pb} 2-\mathrm{O} 3$ & $2.83(2)$ & $\mathrm{Pb} 2-\mathrm{O} 4$ & $2.97(3)$ \\
& & & \\
N3-Pb1-O8 & $119.8(8)$ & $\mathrm{O} 3-\mathrm{Pb} 1-\mathrm{O} 8$ & $83.7(7)$ \\
$\mathrm{N} 4-\mathrm{Pb} 1-\mathrm{O} 5$ & $61.0(7)$ & $\mathrm{O} 7-\mathrm{Pb} 1-\mathrm{O} 4$ & $72.6(7)$ \\
$\mathrm{N} 3-\mathrm{Pb} 1-\mathrm{O} 4$ & $103.7(7)$ & $\mathrm{O} 6-\mathrm{Pb} 1-\mathrm{O} 4$ & $70.6(7)$ \\
$\mathrm{N} 4-\mathrm{Pb} 1-\mathrm{O} 8$ & $82.7(8)$ & $\mathrm{N} 2-\mathrm{Pb}-\mathrm{O} 1$ & $87.2(8)$ \\
$\mathrm{N} 1-\mathrm{Pb} 2-\mathrm{O} 2$ & $91.6(7)$ & $\mathrm{O} 2-\mathrm{Pb} 2-\mathrm{O} 4$ & $116.4(5)$ \\
$\mathrm{O} 1-\mathrm{Pb} 2-\mathrm{O} 3$ & $123.3(7)$ & $\mathrm{O} 1-\mathrm{Pb} 2-\mathrm{O} 5$ & $77.0(7)$ \\
N2-Pb2-O3 & $63.6(9)$ & & \\
\hline
\end{tabular}




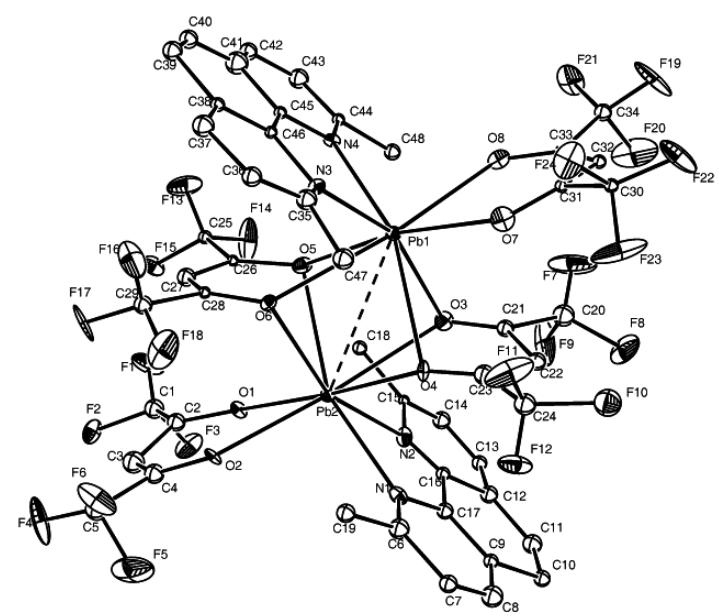

Figure 1. ORTEP diagram of $\left[\mathrm{Pb}_{2}(\mathrm{dmp})_{2}(\text { hfacac })_{4}\right](\mathbf{1})$.

A search was made for weak directional intermolecular interactions in the crystal structure of $\mathbf{1}$. An interesting feature is that there are $\mathrm{C}-\mathrm{H} \cdots \mathrm{O}$ interactions with the distances of 2.64(2) $\AA\left(\mathrm{HC} \cdots \mathrm{O}=3.41 \AA\right.$ and $\left.<\mathrm{O} \cdots \mathrm{H}-\mathrm{C}=141.28^{\circ}\right), 2.62(2) \AA(\mathrm{HC} \cdots \mathrm{O}=3.36 \AA$ and $\left.<\mathrm{O} \cdots \mathrm{H}-\mathrm{C}=136.21^{\circ}\right)$ and $2.55(2) \AA\left(\mathrm{HC} \cdots \mathrm{O}=3.19 \AA\right.$ and $\left.<\mathrm{O} \cdots \mathrm{H}-\mathrm{C}=126.37^{\circ}\right)$, values ${ }^{19}$ that suggest strong interactions within this class of weak non-covalent contacts. ${ }^{20,21}$ There are short F...F interactions with the distances of 2.773(5), 2.936(3) and 2.937(3) A which are less $^{22}$ than the sum of the van der Waals radii for fluorine at $2.94 \AA$ (Figure 2).

The packing diagram of this complex exhibits fascinating self-assembled structural topologies via $\pi-\pi$ stacking (face-to-face with distance of 3.43 and $3.52 \AA$ ) (Figure 2), appreciably shorter than the normal $\pi-\pi$ stacking $^{23,24}$. Consequently, the $\pi$ - $\pi$ stacking and $\mathrm{F} \cdots \mathrm{F}$ and $O \cdots \mathrm{HC}$ interactions allow dinuclear compound to form a hybrid three dimensional network.

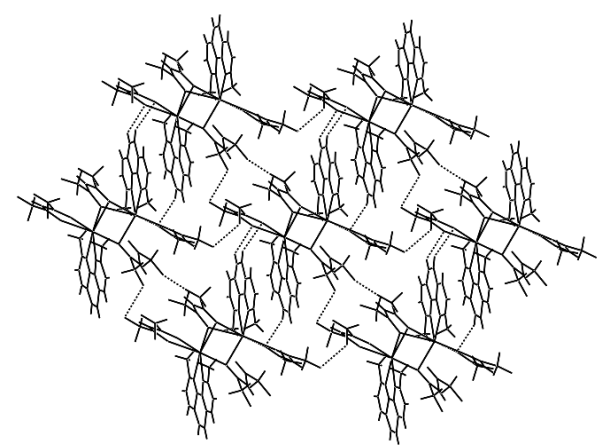

Figure 2. A view, down $a$, fragment of the 3D network of $\mathbf{1}$ via intermolecular interactions

The molecular unit of $\mathbf{1}$ is both dimentionally and structurally different from that $\left[\mathrm{Pb}(\right.$ phen $\left.)(\text { hfacac })_{2}\right] \mathbf{2}$ and $\left[\mathrm{Pb}(\text { bipy)(hfacac) })_{2}\right] \mathbf{3}^{8 \mathrm{a}}$. $\mathbf{1}$ is a dinuclear wheres $\mathbf{2}$ and $\mathbf{3}$ are joined into polymeric chains. However 1 is similare to $\left[\mathrm{Pb}(\text { bipy })_{2}(\text { hfacac })_{2}\right] \mathbf{4}^{8 \mathrm{a}}$ and the similarity of $\mathbf{1}$ and $\mathbf{4}$ further suggests that no significant "lone pair effect" can be operative at the $\mathrm{Pb}$ atoms. The two structures may be regarded as having two; approximately opposed faces occupied either by aromatic (A) or by fluorinated $(\mathrm{F})$ entities and this may explain the segregated nature of its lattice (Figure 2). A possible analysis of this lattice is to regard it as 
being made up of undulating sheets of complex units, with the mean plane of these sheets parallel to $b c$. A view perpendicular to such a sheet (Figure 2) shows that, within the sheet, A faces confront A faces and F confront F. Accordingly, it may be concluded that dimentionally and structurally difference the between $\mathbf{1}$ on the one hand and $\mathbf{2}$ and $\mathbf{3}$ on the other is due to the methyl substituting the 1,10-phenanthroline ligand.

In conclusion, a subtle interplay among the presence of methyl groups on 1,10phenanthroline, strong and weak interactions appears to control the packing motifs in the crystal structure of $\mathbf{1}$. Our current results suggest that, while interactions involving "organic fluorine" have a significant influence in generating supramolecular assemblies in inorganic solids, the general use of these interactions for the a priori prediction of packing motifs is yet to be fully understood and harnessed.

\section{Supplementary material}

Crystallographic data for the structures reported in the article have been deposited with the Cambridge Crystallographic Data Centre as supplementary publication no, CCDC-605297 for $\left[\mathrm{Pb}_{2}(\mathrm{dmp})_{2}(\mathrm{hfacac})_{2}\right]$. Copies of the data can be obtained on application to CCDC, 12 Union Road,Cambridge CB2 1EZ, UK [Fax: +44-1223/336033; Email: deposit@ccdc.cam. ac.uk].

\section{Acknowledgement}

Support of this investigation by Payame Noor University (PNU) is gratefully acknowledged by FM.

\section{References}

1. Braga D, Brammer L and Champness N R Cryst Eng Comm., 2005, 7, 1-19.

2. (a) Paraschiv C, Ferlay S, Hosseini M W, Bulach V and Planeix J M, Chem Commun., 2004, 2270-2271;(b) Akutagawa T, Takeda S , Hasegawa $\mathrm{T}$ and, Nakamura T, J Am Chem Soc., 2004, 126, 291-294; (c) Ren X M, Nishihara S, Akutagawa T, Noro S anf Nakamura T, Inorg Chem., 2006, 45, 2229-2234; (d) Pascu M, Clarkson G J, Kariuki B M and Hannon M J, Dalton Trans., 2006, 2635-2642; (e) Chandrasekhar V, Gopal K, Nagendran S, Steiner A and Zacchini S, Cryst Growth Des., 2006, 6, 267-273; (f) Sanyal N and Lahti P M, Cryst Growth Des., 2006, 6, 1253-1255; (g) Barbera J, Puig L, Romero P, Serrano J L and Sierra T, J Am Chem Soc., 2006, 128, 4487-4492.

3. (a) Jeffrey G A, An Introduction to Hydrogen Bonding; Oxford University Press: Oxford, 1997; (b) Desiraju G R and Steiner T, The Weak Hydrogen Bond in Structural Chemistry and Biology; Oxford University Press, Oxford 1999.

4. Bell T W, Khasanov A B and Drew M G B, J Am Chem Soc., 2002, 124, 14092-14103.

5. (a) Marandi F, McArdle P, Mirtamizdoust B and Soudi A A, J Coord Chem., 2007, 60, 891-899; (b) Marandi F, Asghari N, Ghorbanloo M and McArdle P, J Coord Chem., 2008, 61, 1545-1552.

6. Marandi F, Morsali A and Soudi A A, Z Anorg Allg Chem., 2007, 633, 661-665.

7. Marandi F, Asghari N, Ghorbanloo M, Soudi A A and Mayer P, Z Anorg Alls Chem., 2007, 633, 536-538.

8. (a) Harrowfield J M, Marandi F and Soudi A A, Inorg Chim Acta, 2005, 358, 4099-4103;

(b) Harrowfield J M, Maghaminia S and Soudi A A, Inorg Chem., 2004, 43, 1810-1812.

9 Harrowfield J M, Miyamae H, Skelton B W, Soudi A A and White A H, Aust J Chem., 1996, 49, 1165-1169 and references therein.

10. Sovilj S P, Babic-Samardzija K and Stojsic D, Spectrosc Lett., 2003, 36, 183-196. 
11. Sheldrick G M, Acta Crystallogr., 1990, 46, 467-473.

12. Sheldrick G M SHELXL-97 A Computer Program for Crystal Structure Determination, University of Gottingen, 1997.

13. McArdle P, Daly P and Cunningham D, J Appl Cryst., 2002, 35, 378.

14. Thompson L K, Zhao L, Xu Z, Miller D O and Reiff W M, Inorg Chem., 2003, 42, 128-139.

15. Harrowfield J M, Shahverdizadeh G H and Soudi A A, Supramolecular Chem., 2003, 15, 367-373.

16. Soudi A A, Marandi F, Ramazani A, Ahmadi E and Morsali A, C R Chimie, 2005, 8, 157-168.

17. Hino S, Olmstead M, Phillips A D , Wright R J and Power P P, Inorg Chem., 2004, 43, 7346-7352.

18. Xiao H P and Morsali A, Solid State Sci., 2007, 9, 155-158.

19. Chopra D and Row T N G, Cryst Growth Des., 2006, 6, 1267-1270 and references therein.

20. Reichenbacher K, Suss H I and Hulliger, J Chem Soc Rev., 2005, 34, 22-30.

21. Reger D L, Semeniuc R F, Rassolov V and Smith M D, Inorg Chem., 2004, 43, 537-554.

22. Rowland R S and Taylor R, J Phys Chem., 1996, 100, 7384-7391.

23. Hunter C A and Sanders J K M, J Am Chem Soc., 1990, 112, 5525-5534.

24. Janiak C, J Chem Soc Dalton Trans., 2000, 3885-3896. 


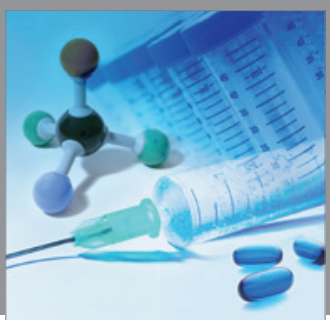

International Journal of

Medicinal Chemistry

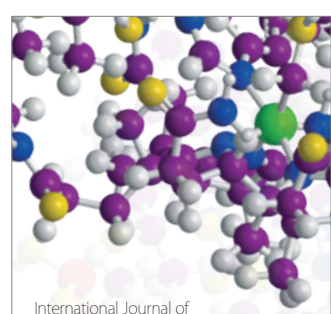

Carbohydrate Chemistry

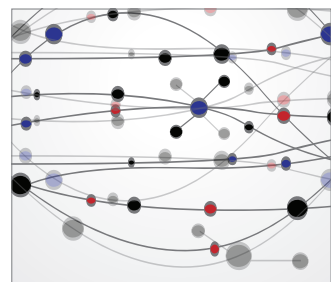

The Scientific World Journal
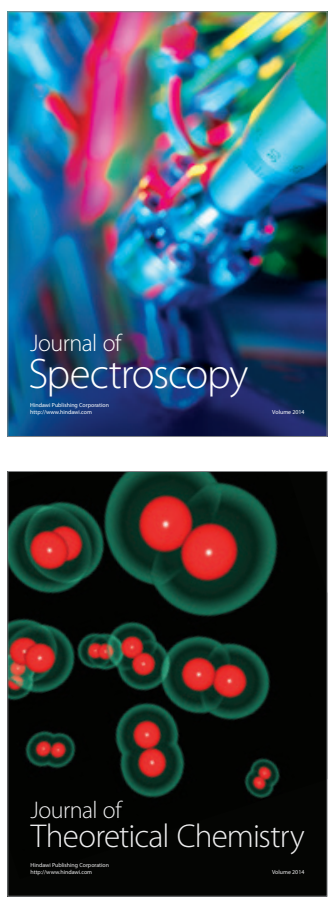
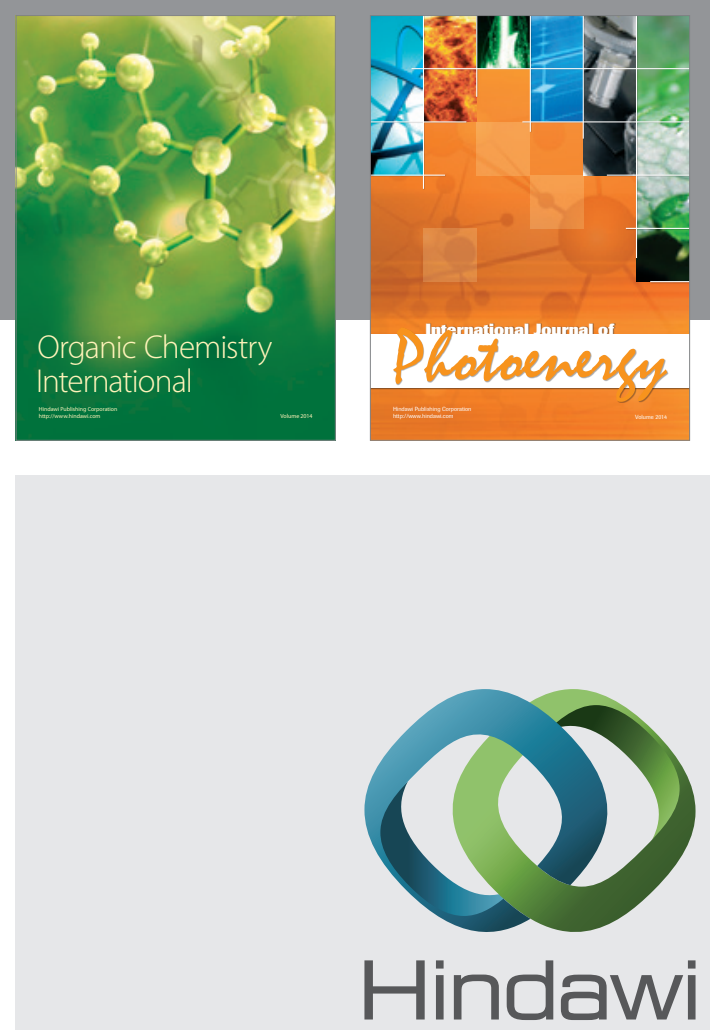

Submit your manuscripts at

http://www.hindawi.com
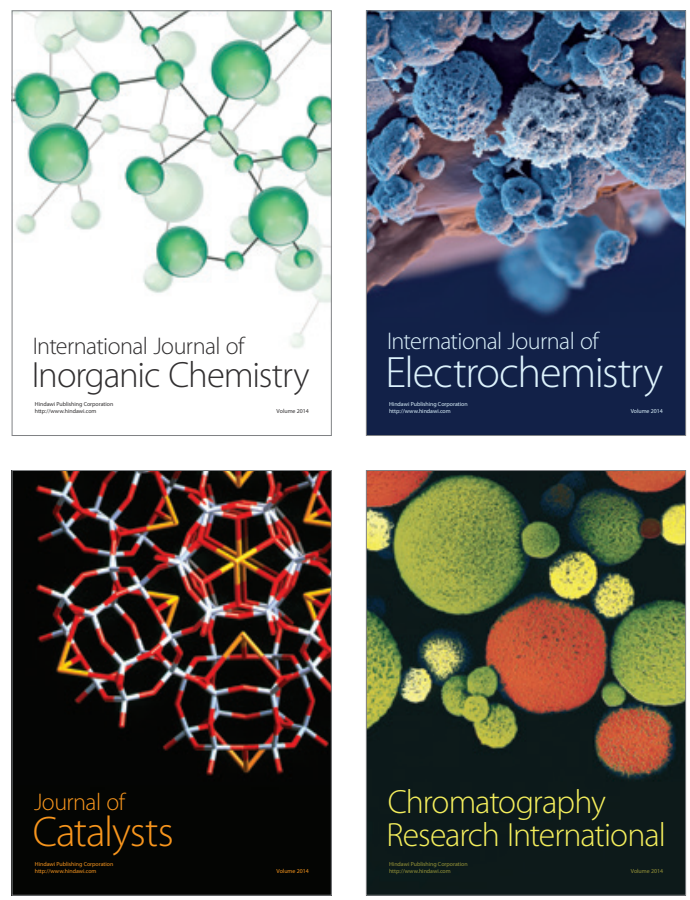
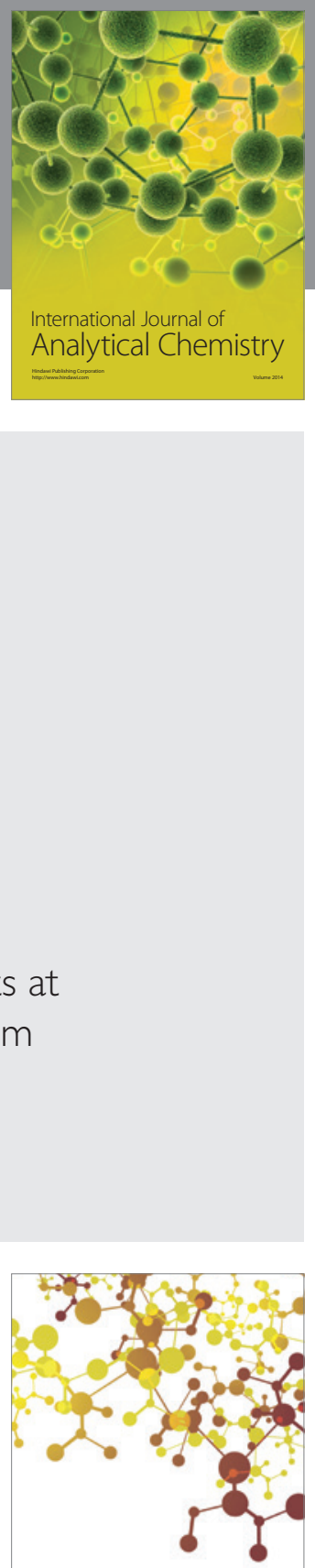

Journal of

Applied Chemistry
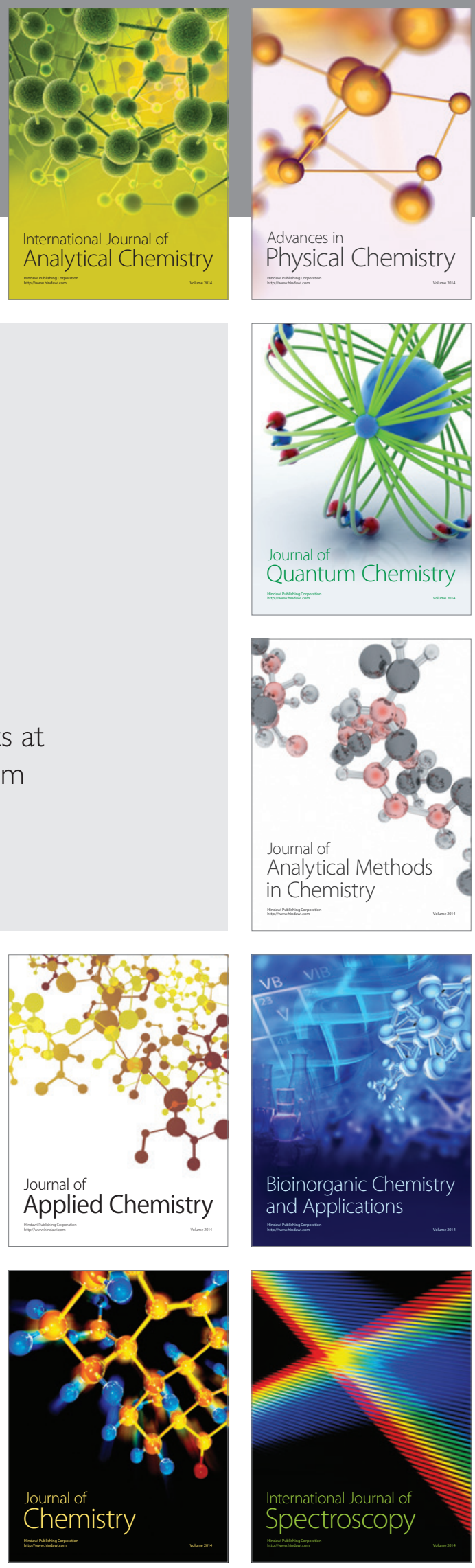